\title{
Albanian Education Issues in the Eye of the Reforms, Priority Development for New Perspectives
}

\author{
PhD. Gladiola Durmishi (Elezi) \\ Departament of Albanian Language and Literature \\ University of Vlora "Ismail Qemali" \\ Address: "Isa Boletini", Street: "Sadik Zotaj" \\ Albania \\ Ass.Prof. Aleks Trushaj \\ Departament of Albanian history - geography \\ University of Vlora "Ismail Qemali" \\ Address: "Isa Boletini", Street: "Sadik Zotaj" \\ Albania
}

\section{Abstract}

Education is one of the most important fields of each company and each system. Through education societies and nations transmit their members knowledge, culture, heritage, values by which society moves forward. Education is also one of the areas that leads not only society, but also strongly influenced by its social changes. The fact that education systems are in permanent change, not shows instability, on the contrary, they serve to better adapt to changes in society. As has happened in our school system, frequent changes made these last 20 years have shown that education is trying to adapt to beat the social changes in our country, but also global. These changes are not being studied and being made in a much less favorable ground conditions in which our educational system was, and from an extreme politicization, not always given adequate fruit and are often perceived by us as experiments. Experimentation in education is not a bad thing, but when the experiment goes spatial and temporal boundaries, then it becomes harmful and negative affects. Recent reforms in education and the debates that have accompanied attest to a growing public awareness of the problems of education and school. These problems seem to belong to the whole society and not just a part of it. Given that the intensity of the reforms has been great, and the time of their commission, relatively short, are noticed and emerge more problems. In this state, which is education in Albania needs a radical reform which should be declared a national priority. What is the concrete solution? I think it is important develop a strategy for a modern education and who have integrated view:

- Processing of pre-university textbooks.

- Giving importance to the practice of students before graduation.

- Focus on Professional Master.

- Development of a model structure the same for theses exams, as in the state, even in private.

- Establishing specific training projects for specific administration.

- Establishment of a model structure evaluation of professors by students and transparency of the assessment.

- Motivate students or students excellent (exellent). 
It is understood that only a reform such problems can not be solved at once. Has initiated efforts time for change in the education system have begun a long way, which will give us direction due to a brighter future. This route requires a consensus between the political forces and the effective coordination of policy factors, the academic community and civil society. Such coordination is successful only if we will and will walk alongside democratic principles.

Keywords: cultural heritage, education, experimentation, problematic, radical reform, pre university education, graduation, training, transparency, academic community.

\section{Introduction}

Generations of researchers, educators and patriots have worked and have been trying continuously for a worthy and increasingly advanced in years, education. Many years of war, slavery, but never straining from hope, illusion and common dreams of all Albanians for language and education. A basic , indispensable and very solid was the will and desire of everyone to learn every gold letter in the single language of our nation. Beginnings of Albanian education started "secretly". Early teachers hold "stealth" Albanian language books to teach thus, being sacrificed in place of the Albanian language. Formation of the unified national literary language became as a great victory of the Albanian people, achieved almost 60 years after the Declaration of Independence. Our literary language is a living expression of the culture of our people, the strength of his historical life, is the result of the efforts of many generations that have worked and fought selflessly, with profound conviction of the importance of successful education development. Albanian schools were fundamental centers of linguistic and literary training of young generations, they educated them with love for their mother tongue and with the belief that our language has inexhaustible treasure values. Fundamental principle along with Independence was the development of education. Everything valued, every sacrifice and effort, valued, blood shed, about what they wanted to achieve, make this nation "owner" of the single alphabet.

For the development of education many more prominent writers and teachers activities, were able to set clear objectives. Deep historical transformations that have been carried out in Albania have brought great changes, League of Prizren gave an incentive to the Albanian educational movement. For further successful education organization, Istanbul Committee created a special committee, which dealt with the definition of a common alphabet, an alphabet which would be only ours , and we would be his only students. In March 1879 the Commission approved the proposed alphabet of Sami Frashëri. This was a very important initiative. With this alphabet was published in Istanbul "Alfabetorja e gjuhes shqipe ." And this was just a start, which was followed by many important successes. On October 12, 1879 was created "Association of Istanbul", which was a cultural and educational one. Program aimed at opening of the Albanian schools, publishing textbooks, which would come to help for the first students of Albanian school. A very important step was taken for the opening of the first Albanian school. On March7, 1887,was opened "Mesonjetorja" under the direction of Pandeli Sotiri. It was an elementary school with secular and national character. The school desks were filled with students who watched their teachers with admiration, while standing on them and diligently listening to each class. After the opening of this school, other schools were opened in provinces of the Albanian territories. In 1891 opened in Korçë the Albanian school for girls under the care of Gjerasin and Sevasti Qiriazi. In these schools were taught not only students but also their parents. The fight against illiteracy had begun to receive the expected responses from most people, who wanted to fight it.

In 1928 Law on Education was approved, which predicted that primary education should be mandatory. Later were opened primary schools, secondary schools, general and professional. Special contribution to the development of education was given by schools, but also by foreign educational institutions. During the 1930s there was great development in literature. There were published novels, volumes in prose and poetry. In 1946 Education Reform was approved, which reconfirmed that primary education be compulsory and declared war on illiteracy. But a very important step was the opening of a Pedagogical Institute in Tirana on December 20,1946. This high school became the nucleus of the University of Tirana, which was opened in 1957 with several faculties. All these events brought new standards in the development of education. But although every effort resulted successful, yet there were discussions about a very important fact, standard Albanian . "The Albanian people wherever they are , they have a unified national language." This was the conclusion of the Congress of spelling of the Albanian language. , In 1972. after the discussions at the congress, it was decided that Tosk will be the basis 
In the coming years, education received a more extensive spreading in Albania. After the fall of the dictatorship, it became massive education. Today every relevant city in Albania has got a university, whether public or private, or both existent.

Is this an important step in the development of education?

Maybe it is. Probably because there are many issues that must be considered. To some extent state universities have managed to be successful, but normally, not everything has proved perfect. There have been difficulties, but there have been successes in the development of education.

Education is one of the most important fields of every society and every system. Through education societies and nations transmit to their members knowledge, culture, heritage, values by which society moves forward. Education is also one of the areas that leads not only society, but is also strongly influenced by its social changes. The fact that education systems are ever changing, it doesn't indicate instability, on the contrary, they serve to better adapt the change of society.

Just as happened even in our school system, frequent changes made these last 20 years have shown that education is trying to adapt to the social changes in our country, but also with the global. These changes not being studied a lot and being made in one more less favorable ground situation in which our educational system came from and one extreme politicization, not always have given the appropriate results and are often perceived as experiments. Experimentation in education is not a bad thing, but when the experiment passes spatial and time limits, it becomes harmful and influences negatively.

The XXI century, has started which is already characterized as the century where everyone's chances in life will be defined, more than ever, on the degree of education. We think that it is necessary to do a realistic analysis of how far we have reached with the difficult process of democratic development to education, as a determinant condition for the level of training of the young generation.

The biggest resource for Albania is the young age of population, the youngest in Europe. Namely, this new generation that grows nowadays requires the right degree of educational and cultural training, which will determine the pace of economic and social development of the country and the destiny of democracy so fragile in Albania. The issue lies in the fact that the Albanian education leaves much to be desired. When talking about the Albanian education we include pre university , university , and postgraduate education. It will be addressed specifically what are the evident problems in pre university education and pointing to curriculum content and level, but not only this, the first reform and competition to enter the university. At university troubles come and take larger proportions. So, talking about the material base, laboratories, developing conditions, schedules, graduation and up to the candidacies for the election of the rector at university. Last but not least, we will address current issues in postgraduate education, where we will stop at the loss of human capacity, leaving the country for benefiting a professional master. Below we express our opinion on these issues, which appear as problematic in our country. Education reform launched in 2005, was the State Matura reform. But why did it fail and how it is proceeded nowadays? The 2005 graduates caught by the reform, which led profoundly to change their lives. They were informed that to win the branch of Journalism they have to learn literature rationally and to win the branch of medicine should learn biology and chemistry. State Matura comes with changes and gives the palm of the first set as the criterion making points on the average of four years. These high school students have four years to prepare for the respective subjects, than the mean opinion was not useful, being found so unprepared and without time to recover anything after four years had gone. This was the situation at the beginning of the educational reform. How is the situation nowadays? Today graduates compete with the same system that began in 2005 by taking into account the mean and exam scores. But can not set aside the fact that these marks that draw an average, after four years are taken in different ways. One studies in private school and it is not the real result he has got, someone comes somewhere from the remote areas, where good grades are easily set effortlessly and someone else gets them in an unscrupulous manner "buying". In October the graduate see his name listed first on the list of branches nearly impossible for one to get there, at the end, having all year. Thus, we see that there is no one without touching the rates of university.

The current situation of the education system indicates that it must undergo a radical reform, comprehensive and deeply democratic. Recent reforms in education and the debates that have accompanied them, reveal a growing public awareness of the problems of education and school. These problems seem to belong to the whole society and not just a part of it. Since the intensity of the reforms has been great, and the time of their accomplishment relatively short, it is noticed that in addition to the progress made, there are new problems in their implementation. It is understood that only with a reformation 
such problems can not be solved at once. Thus emerged the problems that in some cases, if not treated with appropriate seriousness may leave consequences in the education of future generations. Starting with 9-year-old system, a new gymnasium, alter texts, state Matura etc

Reforms carried sometimes hastily, found the teachers unprepared to cope with all these changes. If the aim and the main achievement of new curriculum reform was a change of conception in education, thus putting the student at the center, it's not understood by all teachers or it is realized superficially. To establish student-centered learning it doesn't mean to content simply with using several teaching techniques in teaching literature known as the "techniques of student-centered learning", but need to change the mindset of teaching, should be changed the viewpoint. Teaching and schools must serve students and if that fails, the mission can be called unrealized, or a failure. Even today, there are teachers who see the student as an object and not as a subject. They forget that every individual has a feature that the educational system and especially the teacher should point out. Students are seen as the problem rather than the solution; students point out weaknesses, but not achievements. This view, though not malicious becomes the cause for creating uncomfortable situations in learning. Here starts the real teacher-student conflict. And everything is focused on grades. Evaluation is thus done by an incentive tool, reflective of results, a means of psychological pressure and a source of conflict. School from a friendly place, turns back at the nightmare of many students and youngsters, who rather than take in it how education should form their behavior in life, the student at society and beyond, they take, the first lessons on how to 'pass more easily.

The impact of society and the great pressure that our society is making to promote achievement of results, has the opposite effect, not by increasing desire and interest to learn, but to have a diploma. If this reform in some cases displays its problems, it does not mean that we should go back, but look at causes, problems and find the best solution. The most sensational and worrying problems, whenever the school year started had to do with texts. The lack of them, or selling illegally, poor quality in some cases, insufficient quantity and above all, their content and loads of great deficiencies in pedagogical apparatus, became a problem that accompanied school during transition. Alter texts reform in pre- university education solved many of the problems raised. It can not be assumed that the level of their scientific or pedagogical quality reached the highest standards, but it put education reform in a track and led to changes in the perception of the text, not as the most important tool of teaching, but as a useful tool for the student. What seems to remain unfulfilled in this reform has to do with the teacher. As long as there will be teachers who for various problems or uncertainties, as well as scientific errors will be justified with "it's in the textbook" we can say with conviction that the reform is not realized as it ought to be. New problems displayed with alter texts reform have to do with the translated texts, which really belong to the natural sciences and as such, of course, that may be the best in quality and content than the texts prepared by the Albanian specialists but we must not forget the country's traditions , these texts come from and, above all, the translation problems, that sometimes might be funny and amatory. Publishing houses from the desire to be more competitive in the market forget that they do not deal with a consumer product, but with an important material for the formation of future generations.

What can seriously damage this reform and the education system has to do with clientlist interests of publishing houses and authors of texts. It is good, for the adoption of textbooks, to apply a more open and transparent manner, including more teachers as implementers and better experts of school problems and programs. Thus you may avoid any outside influence and harmful monopoly. A reform can not be understood without the human resources that give it real value. The teacher is the main actor and the most important factor that gives life and embodies the policy reforms. But what is done for the teachers in these last 20 years? As the positive side, of course, even in this case, there is a need for discussion. This question would get more answers, if you get into the calends of politics, but for the sake of truth, it must be said that the teacher is not doing enough. In these 20 years of transition is observed that the teaching profession, which was once highly sought and highly valued, is already at the end of the preferences of young people. The main factor that affects, of course, has to do with salary. In a market and free competition economy, it is natural that everyone will require the best and it is known that the teaching profession is not well-paid, but the abandonment of the profession in this extent, it's not only for the payment side. Teacher is neglected by society. All are remembered for him on March the 7th or when you want to criticize the "courses" that even though they are an ugly phenomenon of education, are not the top of corruption. Teaching is perhaps the only profession that is still considered as under communism. All equal, and all paid equally. So why should a teacher try to raise his professional side? Just for fun, when for work and different fatigue and uneven responsibility all teachers are paid the same, according to a scheme that seems absurd.

A scheme that has been operating only under socialism, categorizing teachers according to seniority when it is known that, being older in a job does not mean that you are always the best. This has made all the reforms, changes, developments in 
education being followed with indifference by a part of teachers since for them it is enough to have a degree, a friend, an acquaintance, and so on and the position and wages do not differ. This is a factor that teachers profession today is required by not high quality students, because they know that having the bachelor degree will find a place to sit comfortably for almost "40" years. This practice should be stopped, because it is creating serious problems in education. Teachers, like any professional should be motivated in his professionalism, but on the other hand should be evaluated and should be given a status, which is not easily broken by the winds of political change.

Another aspect related to the preparation of teachers has to do with youth and students who choose this profession. Universities and schools should create bridges to give these young people, necessary skills and habits as knowledge and understanding is received during the study. We all know how difficult it is to pass from the theory which is obtained in schools to concrete practice, in reality. This requires practice, which does not lack in university study programs for teachers' branches, but their implementation and organization have room for improvement. Students can not get at school all the knowledge they need to be good professionals, moreover when most of the professors are disconnected from the pre university system, but at school they can learn more about what they need. This is achieved by entrusting this task to a specialist teacher and not by chance, as often happens. University and education departments must think of this, to create mentors and teacher of quality in practice who of course should be evaluated. Good practice or part-time employment at schools, of just graduated students might help. They'll gain skills and work habits, but considering this as a period of active practice either free or with other funds.

Focusing on development of education, one can not leave aside infrastructure and school environments that in recent years have changed a lot. Today a part of big city schools and important urban centers have a modern infrastructure. It is true that the number of students per class is not spread uniformly, and this is a result of major demographic shifts and changes occurring in the population structure. Problems in infrastructure and school environments appear to their management.

Today a school director or her directory almost have no authority as regards school facilities and administration. A school director can not manage school environments according to interests of the school and community, because primarily school has no budget and there is no law that regulates the relationship. So even if a director will make an effort to improve situation in his school, these will be carried as a favor for the sake of the director rather than work and school aid. As the director shouldn't be any more a chief teacher, he must be given, the role of school manager that belongs legally, but also responsibility and competence.

Let us stop at another point, dealing with material equipment and laboratories. Albania is not rich enough as to leave material capacities of institutes and universities without any real function. Laboratories and buildings should be placed entirely at the service of students. Within universities should be taught laboratories that are required to make important routine services (as in disease control, products etc..). Technology transfer services are considered as essential functions of modern universities. One of the main weaknesses of our higher education, that continues to differentiate it in relation to higher education in other countries, is the very limited research activity of academic staff, which has been particularly pronounced in sectors of experimental technique, thus making that the main activity is limited mainly on pedagogical plan. Therefore the mission of university, in faculties, is focused only on the syllabus leading to the loss of physiognomy of the university as a center of learning and research. Reducing research activity especially in applied and technical sciences, associated primarily with institutional financial factors, lack of the necessary laboratory and the inability to integrate into the European Community research programs, has made remain untapped the intellectual potential of our universities. Not to forget the other fact, university schedules are inappropriate. A student starts at 08:00 and ends at 18:00. At least in most universities it happens so.

The question arises, where will this student find the time to learn for the next day or will he postpone his studies until exam season approaches? It should be found an adaptable solution, which give the opportunity to organize his study and leisure time . Not to mention the fact that today student's connection with the book is more distant than before. If you see statistics figures, today you find that $90 \%$ of students are connected to the Internet, the latest technology, cafe exits thus forgetting the book. This performance, then influences the teaching process, neglecting school and therefore it should be more demanding for teachers and professors, who should encourage a bit the willing spirit. Only in this way, it is realized clearly, the democratic purpose of education. Is education in Albania a simply convertible system in all countries of the EU or not?

Education is the key point and a safe step to reinforce self-confidence for everyone wherever located. A recognized degree everywhere is a "professional ego." When knowledge is measured and evaluated according to the same system, it makes 
possible the group harmony. But one of the most disturbing phenomena in the current structure of our education, is partial graduation of students or part time study, which distinguishes our university education from that of other European countries. Universities like Tirana, Elbasan and Shkodra possess these studies. This strategy, which until now could be considered positive financially and quantitatively has brought a reduction in the level of quality of training young specialists. The quality of students attending correspondence system is lower than that of the regular day students . Likewise, the lower is the level of their training because of not attending lectures. Under these conditions, the students of both systems, despite these significant differences, are considered the same and get the same degree, which in the context of an administrative and political subjectivity can be associated with consequences. On the international level, various international organizations, specialized in the field of recognition of diplomas, are seeking information on the differences between the two systems of graduation. Would it be fair to answer that officially there is no difference? Evidently part time graduates are not capable of facing tasks rather than those of full-time, so this is a problem which really threatens our future.

In PIZA-s's official ranking, our country ranked the 6th from the end of the list of 65 countries included in the study by the OECD, leaving behind only Panama, Peru, Azerbaijan, Kyrgyzstan and Qatar. OECD ranking classifies Albanian students significantly less prepared than their Bulgarian, Montenegrin or Serbian neighbors, both in writing, math and other sciences. According to the same report of PIZA 2010, Albania is a country with the weakest educational level. Statistics speak, from 2000 to 2010 Albania has scored 20 points in the rankings of education that makes the Organization for Cooperation and Economic Development, being one of the three countries with the greatest progress. A fact that is strongly identified by the Ministry of Education. The Minister Myqerem Tafaj said: "Albania is rated among the three countries that have the greatest progress in the education of students in the last 10 years." But this indicator that compares the progress made from 2000 to 2010, if taken detached presents a slightly different situation from the truth. For a country with a developed educational system, such as the OECD countries, it would be impossible to have such a result as that of Albania. In this logical flow we have advanced, but we can't be compared to the standards that today policy claims, leaving a lot to be desired as in the pre-university education (textbooks, grades, competition for the university), but also in the postgraduate education (graduation, schedules, laboratories).

The consequence of all the problems treated from the beginning, is the loss of human capacity, which is a phenomenon that affects each day more the country. Thus, the solution is the removal or acceptance of conditions in universities. It is noticed a removal of students from Albanian universities, but not alone, many of the professors are mostly away for full qualification degrees. Students are leaving to gain a professional master, which our country hasn't still managed to secure. Seeing that there is an effort to master, but it still remains as an attempt to achieve standards rather than a full realization. Our universities really suffer emptying and increasingly mediocrity. "Canada, and the U.S.A will enjoy the fruits of this massive" brain grain "that Albania will pay dearly." Many talented students leave school because of unbelief set in Albanian universities. This is a reality that must be accepted and should not be treated emotionally. We should not continue with the rhetoric according to which our schools are among the best. In the circumstances being, education in Albania needs a radical reform, which should be declared a national priority. What is the concrete solution?

\section{Conclusion}

-We think it is important the processing of a strategy for a modern education, that might be integrated, aiming at:

-Text processing in the pre university education;

-Giving importance to the practice of students before graduation;

-Focus to Professional Master;

-Creation of a model of the same structure for exam thesis, both in state, and in the private;

-Establishing specific training projects for specific administration;

-Establishment of a model structure of assessing professors by students and the transparency of this assessment;

-Motivating students or excellent students.

Time for a change in the education system, has initiated. We have started a long way, which will give us the right direction for a better future. This road requires a consensus between the political forces and the effective coordination of the actors 
from politics, academic community and civil society. Such coordination is successful only if we show willpower and will walk alongside the most developed democratic principles. Only in this way will not destroy tradition, moreover will know to appreciate it at any time, as required. All that is done in decades for our Albanian education, hoping to find the most valuable way to progress.

\section{-Bibliography}

[1] The history of the Albanian people, Tirana, 2009

[2] ISMAJLI, R. (2005). Standard language and history of identities. Tirana, 2005

[3] Kule, Dh. Albanian Education, Tirana, 2010.

[4] Likaj, E. Reports linguistic and cultural economy of language,

[5] International seminar Language, Literature and

[6] CultureAlbanian, Pristina, 2006, 25/1

[7] Pedagogical magazine: On the Problems of Education, Vlora, 2011

[8] Tafaj, M. The interviews on education's problems, 2011

[9] Spelling Albanian language, Tirana, 1973

[10] The history of the Albanian people, Tirana, 2009

[11] MES National strategy, Tirana, 2009-2013

[12] Memushaj, Standard Albanian R. (how to speak and write), Tirana, 2005

[13] MULAKU, L. Some current issues of standardization of Albanian literary

[14] "Language in school ", Prishtina, 1989

•shënim:

shanset-mundësitë; problemet evidente -problemet e dukshme; procedohet -zhvillohet; amator-fillestar; reformë radikalendryshime rrënjësore; redukton-minimizon; potencial intelektual-fuqi mendore; adaptoj-përshtat; neglizhoj-lë pas dore; fenomen-dukuri; strategji-plan; progres-zhvillim; standard-nivel; gjeneron-përtërin; vlerson objektivisht-mat ashtu siç është, realisht; abandonoj-braktis; brain drain-mëndje e ndritur.

-Note:

opportunities-possibilities; evident problems -apparent problems; proceed-develop; amateur- beginner; radical reform radical changes; reduces-minimizes; intellectual potential-mental power; adapt-adjust; neglect-flaunt; phenomenonoccurrence; strategy- plan; development- progress; standard-level; generates- renew; assess objectively-measured as it is, really; abandon -forsake; brain drain - the brightest minds. 